\title{
EFFICIENCY OF THE ELDERLY PHYSICAL RECREATION PROGRAMME AIMED AT IMPROVING FUNCTIONAL EFFICIENCY AND QUALITY OF LIFE
}

\section{EFEKTYWNOŚĆ PROGRAMU REKREACJI RUCHOWEJ OSÓB STARSZYCH W ZAKRESIE POPRAWY SPRAWNOŚCI FUNKCJONALNEJ I JAKOŚCI ŻYCIA}

\author{
Anna Leś ${ }^{1(\mathrm{~A}, \mathrm{~B}, \mathrm{C}, \mathrm{D}, \mathrm{E}, \mathrm{F}, \mathrm{G})}$, Ewa Kozdrońn ${ }^{1(\mathrm{~A}, \mathrm{E}, \mathrm{F})}$, Ewa Niedzielska ${ }^{1(\mathrm{E}, \mathrm{F})}$, Michał Kozdroń $^{2(\mathrm{E}, \mathrm{F})}$ \\ ${ }^{1}$ Faculty of Tourism and Recreation, The Józef Piłsudski University of Physical Education in Warsaw, Poland \\ ${ }^{2}$ Faculty of Rehabilitation, The Józef Piłsudski University of Physical Education in Warsaw, Poland
}

Authors' contribution Wkład autorów:

A. Study design/planning zaplanowanie badań

B. Data collection/entry zebranie danych

C. Data analysis/statistics dane - analiza i statystyki D. Data interpretation interpretacja danych E. Preparation of manuscript przygotowanie artykułu F. Literature analysis/search wyszukiwanie i analiza literatury G. Funds collection zebranie funduszy
Tables: 1

Figures: 2

References: 31

Submitted: 2017 Jan 18

Accepted: 2017 Apr 04

\section{Summary}

Background. The study aimed to evaluate the effectiveness of the Physical Recreation Programme for the Elderly designed by Ewa Kozdron intended to improve the functional efficiency and quality of life of women over 60 who participated in the programme.

Material and methods. The research involved 73 females aged 60-74 who participated in the Physical Recreation Programme for the Elderly. The research used the author's questionnaire, i.e. EQ-5D questionnaire and Functional Fitness Tests (FFT).

Results. The results of our research confirmed a positive relationship between participation in a regular physical activity, the declared level of functional fitness and the perceived quality of life.

Conclusions. A positive relationship was found in the study group between participation in regular physical activity, the declared level of functional fitness and the perceived quality of life.

Keywords: quality of life, physical activity, the elderly

\section{Streszczenie}

Wprowadzenie. Za cel badań postawiono próbę oceny efektywności Programu Rekreacji Ruchowej Osób Starszych (autorstwa Ewy Kozdroń) w zakresie sprawności funkcjonalnej i jakości życia kobiet po 60. roku życia, biorących udział w programie.

Materiał i metody. Badaniami objęto 73 kobiety w wieku 60-74 lata, biorące udział w Programie Rekreacji Ruchowej Osób Starszych. W badaniach wykorzystano autorski kwestionariusz ankiety, kwestionariusz EQ-5D oraz próby sprawnościowe FFFT.

Wyniki. Wyniki badań otwierdziły dodatnią zależność pomiędzy uczestnictwem w regularnej aktywności fizycznej, deklarowanym poziomem sprawności funkcjonalnej, a odczuwana jakością życia

Wnioski. W badanej grupie stwierdzono dodatnią zależność pomiędzy uczestnictwem w regularnej aktywności fizycznej, deklarowanym poziomem sprawności funkcjonalnej, a odczuwaną jakością życia.

Słowa kluczowe: jakość życia, aktywność fizyczna, osoby starsze

\section{Introduction}

Increasing human life expectancy over the past several decades has resulted in enlarged 60+ generations in the developed countries. Old age is treated as a natural and necessary stage of human life, in which the organism undergoes involuntary motor processes underlying biological changes. They concern, among others, a reduced range of motion in the joints, lower muscle strength, a decreased motor ability to adapt to the environment, a slower reaction to the changing situations or impaired ability to perform more complex activities. One of the more visible symptoms of ageing are qualitative changes of spontaneous movements and their reduced speed [1].

The elderly tend to limit physical efforts in everyday life, pursue physical comfort (motor laziness), eliminate physical efforts as part of caring for own health. The response time to external stimuli as well as the smoothness and flexibility of the performed activities is extended. As a result of these unfavourable changes, the number of falls among the elderly increases. A higher mortality rate is also associated with a slowing-down reaction and a decrease in muscle strength. Further, limited mobility in the joints of the lower limbs and spine is more

Leś A, Kozdroń E, Niedzielska E, Kozdroń M. Efficiency of the Elderly Physical Recreation Programme aimed at improving functional efficiency and quality of life. Health Prob Civil. 2018; 12(2): 110-117. https://doi.org/10.5114/hpc.2018.74584

Address for correspondence / Adres korespondencyjny: Anna Leś, The Józef Piłsudski University of Physical Education in Warsaw, Faculty of Tourism and Recreation, Marymoncka 34, 00-968 Warszawa, e-mail: les.anna@wp.pl

Copyright: (C Pope John Paul II State School of Higher Education in Biała Podlaska, Anna Leś, Ewa Kozdroń, Ewa Niedzielska, Michał Kozdroń. This is an Open Access journal, all articles are distributed under the terms of the Creative Commons Attribution-NonCommercial-ShareAlike 4.0 International (CC BY-NC-SA 4.0) License (http://creativecommons.org/licenses/by-nc-sa/4.0/), allowing third parties to copy and redistribute the material in any medium or format and to remix, transform, and build upon the material, provided the original work is properly cited and states its license. 
common with age. Accordingly, the ability to perform more complicated movements, e.g. asymmetrical ones or undertaking several actions at the same time, disappears. The muscular strength, endurance, speed and flexibility as well as physical fitness are significantly deteriorating, which affects physical fitness [2].

Between 50 and 60 years of age, the incidence of involuntary changes can be observed (mainly the ones that impact one's motor skills), although they tend to be less dynamic between 60 and 70 years of age. The weakening response to stimuli, deteriorating memory as well as sight and hearing, problems with maintaining balance most often lead to a loss of faith in one's own strength, capabilities and efficiency [3]. Between 65-74 years of age, the primary role of regular physical activity is to retain motor skills in independent functioning and participation in social life [4].

The changes taking place in the physical sphere, psyche and social status of an older person have a clear influence on their motor skills and physical activity [5,6,7]. These changes consist in reducing the speed of motor learning, lowering mental performance and severe changes in emotional adjustments. The high dynamics of cultural and social changes, the rapid pace of technical and IT progress often lead to a sense of isolation and alienation in the surrounding environment. All this means that the older generation withdraw from social life and live off the beaten track. There appear changes in old people's personality, i.e. narrowing interest in what happens around, a reduced mental activity, excessive caution in making decisions, assuming conservative attitudes towards new things, focusing on own matters, and finally a conviction about own infallibility as well as becoming emotional [6].

In conclusion, psycho-emotional changes related to ageing demonstrate a clear relationship between biological, health and social changes. One's dependence on the environment increases, whereas the attitudes, behaviours, needs for security change, causing withdrawal from the former forms of activity. There emerge hypochondriac tendencies, self-centeredness, need to be accepted and activated. At the same time, the elderly limit their contacts with other people, exhibit lower self-esteem and social prejudices. What seems positive is that they do not lack leisure time at that stage of life.

The most critical problems of older people consist in loneliness, diseases, disability, impoverishment and a sense of uselessness. All may lead to some marginalisation of the elderly as a social group, which is visible in their gradual elimination from active professional and social life at the time they retire. Therefore, it seems crucial that seniors remain active in everyday life for a long time, actively participating in social life and developing and pursuing their passions. This way, they can decide for themselves and feel satisfaction at the same time.

Also, regular physical activity has an indirect influence on life expectancy, improvement of physical fitness, mobility and extension of functional activity in daily life [8]. Functional ability, as well as general physical condition, are equally crucial for the quality of life in older age. Further, functional ability determines the ability to cope with the daily challenges $[9,10]$.

Summing up, it can be stated that particular attention should be paid to functional ability in older age because it can prevent senility and diseases of old age, as well as help in the rehabilitation process. A physical effort has a beneficial effect on the entire body. It stimulates the nervous system (relieves neurotic conditions and sleep disorders), respiratory system (improves the mobility of the chest, diaphragm and ventilation) and blood circulation (it causes the fibres of the heart muscle to grow and better supplies the heart and tissues). Regular physical activity can significantly contribute to slowing down the process of ageing and ensure greater selfreliance and independence in daily life. Thus, it becomes an opportunity to improve people's quality of life and the way they perceive life satisfaction - it is a chance for successful ageing $[8,9]$.

The literature on the issue provides at least several different definitions of quality of life. Most authors emphasise the complexity of this issue, pointing both to the objective and subjective aspect of life quality $[4,7,11,12,13]$. In objective terms, the quality of life may comprise health and efficiency, whereas in objective ones, economic status, housing conditions, natural environment and social environment [14]. In subjective terms, it will refer to self-assessment of, for example, health, living conditions, contentment and happiness, hope or loneliness and independence in everyday life (also in terms of physical fitness) [7]. However, as Banka [15] informs, the relationship between the objective and subjective aspects cannot be unambiguously determined. The literature provides references to the complexity of the notion of quality of life. For example, authors Baumann, Seed and Forests [7,16,17] stress that life satisfaction in older people is conditioned by both objective and subjective aspects of the quality of life. According to Zielińska-Więczkowska and Kędziora-Kornatowska, it is the health condition of the individual, especially his/her level of physical fitness, which can be seen as a significant determinant of life satisfaction in the period of late adulthood. Other crucial aspects are life activity, the level of education, life optimism, family and the sense of coherence [18].

As for the functional ability, the literature defines the issue in more consistently. Functional fitness (ADL) is understood as the ability to be independent of others in fulfilling one's primary life needs [29]. According to Webster's New World Medical Dictionary [30], functional fitness refers to everyday activities, economic activities, 
self-service, mobility and rest. Adamczyk, Sosnowski and Chmara-Pawlińska, [31] understand functional ability as the ability to deal with everyday activities. Performing a simple task requires the person's willingness and ability to perform, efficient nervous pathways as well as an efficient executive system, whereas the deficit of physical fitness adversely affects one's well-being and quality of life. Efficient, independent functioning is of great practical and emotional importance for the patient as it has a positive effect on his/her physical and mental condition and promoting a sense of independence [31].

All these definitions of functional efficiency share some common elements. These include moving around, eating, maintaining hygiene (e.g. washing), controlling the physiological activities (using the toilet), dressing up, preparing meals and hot drinks. Another term which the literature uses to refer to functional ability is activity efficiency [29].

\section{Objective of the work}

Bearing in mind the close relationships determined by the literature between the quality of life and physical activity of the elderly, the following study aims to evaluate the effectiveness of the Recreation Programme for the Elderly devised by Ewa Kozdroń with regard to functional abilities and quality of life of women aged 60 years and older who participated in the study.

\section{Material and methods}

The research was conducted in 2015 in a sample group participating in the Recreation Programme for the Elderly [19]. The study involved 73 women aged 60-74, who took part in a 6-month PA programme as well as a summer camp designed for seniors. Before joining the programme, its participants were to provide their written consent as well as the physician's or GP's statement indicating that there were no contraindications to undertake specific physical activity.

The research consisted of two parts: questionnaire surveys (subjective assessment) and performance tests (objective evaluation). The study was based on a diagnostic survey method using the author's questionnaire, which concerned self-assessment of own health and functional ability, including self-service, mobility and daily performance. The procedure consisted of three parts, i.e. self-assessment of one's health, physical fitness and physical activity. The respondents answered 10 questions about their well-being, functional ability and physical activity. The questions regarding self-assessment of own health and functional fitness were asked twice (precisely in the same form), before the commencement of physical activities and after participation in the camp's activities. This allowed for comparing the changes that occurred in the self-assessment of these two aspects after the regular physical activity cycle ended. The questionnaire was conducted by the interviewer (the author) using a direct technique, which allowed her to obtain additional information about the elderly's satisfaction gained during the classes and prevent the respondents from sharing their answers.

The EuroQol 5D test (examining the quality of life in relation to self-assessment of one's health and functional ability, www.pdsurg.bham.ac.uk ) was used to evaluate the quality of life of the surveyed women. The test consisted of 5 questions about well-being and daily fitness on the day of the test on a scale from 0 to 100. Questions 1, 2 and 3 concerned everyday fitness, whereas questions 4 and 5 - the person's mood. The answers to the questions were given point values: $\mathrm{a}-$ there are no problems ( $3 \mathrm{p}$.), $\mathrm{b}$ - there appear some ailments ( $1 \mathrm{p}$.), $\mathrm{c}$ - there are constant ailments $(1 \mathrm{p}$.).

The functional scale was assessed using the ADL (Activity of Daily Living) scale - the efficiency assessment scale in the field of everyday activities [20]. Functional fitness was examined in three aspects: personal selfservice (P-ADL), instrumental ability (I-ADL) and mobility.

For an objective assessment of one's functional fitness, 4 activities were selected from The Fullerton Functional Fitness test, which enables evaluating all physiological properties that support and are necessary to maintain the independence and safe daily activity of the elderly. The test assessed aerobic fitness, flexibility, strength, agility and dynamic balance [21, 22]. The following exercises were made:

1. chair stand for 30 seconds (assessing the strength of the lower body, the number of repetitions);

2. 2-minute step (evaluating endurance, the number of right and left leg movements;

3. chair sit and reach (measuring the lower body flexibility);

4. arm curl (measuring the upper body flexibility).

The outcomes of the measurements of individual somatic and functional variables are presented in the form of arithmetic means and standard deviations. The differences between the mean values obtained before and after the programme were assessed by dependent-t test. A one-sided test was used as it was assumed that the exercise programme would improve the functional efficiency of the examined women. 
The analysis of the questionnaire data was carried out using the chi-square function in a logarithmic form [23]. The interdependencies between the studied variables were evaluated using Pearson's correlation coefficients. The analysis applied statistical functions of the Excel spreadsheet. The level of $\mathrm{p} \leq 0.05$ was considered as significant.

\section{Results}

The comparison of the findings obtained in the first stage of the test (before the beginning of the classes) and after the end of the camp is presented below.

\section{Self-evaluation of the respondents' health}

While comparing the self-assessment of the health of the examined women before taking regular physical activity and after the 6-month period of the PRROS programme and the camp, a positive relationship was observed in the self-perceived health level, which, however, it was not statistically significant. The observed differences in self-assessment of own health are as follows (before the program vs after the program): good health (12\% vs $25 \%$ ), good health ( $28 \%$ vs $40 \%$ ), average ( $52 \%$ vs $32 \%$ ), rather bad ( $8 \%$ vs $3 \%$ ), bad - no indication.

Furthermore, the respondents would indicate their ailments before participating in the PRROS programme and after it ended. Both before the physical activities started and after the course ended, the women would often complain of back pain ( $77 \%$ vs. $67 \%$ ), joint pain ( $59 \%$ vs. $60 \%$ ), difficulty falling asleep (57\% vs. 51\%) and fatigue (41\%) vs. $40 \%)$.

\section{Functional ability}

In the self-assessment of the functional ability of the respondents, there were positive changes after the PRROS programme had been completed. In the respondents' view, there was an improvement in the performance of daily activities - in preparing own meals, hot drinks, and doing heavy housework. The women would indicate that they had become more efficient and independent in moving and taking care of themselves (washing, dressing, cutting off nails). Detailed percentages of the respondents' answers before the commencement of the motor activities and after the end of the programme indicate the following progress in performing activates without assistance: going outside (87\% vs. 88\%), going up and down stairs (75\% vs. 88\%), moving around the apartment (85\% vs. 89\%), washing up, bathing (4\% vs. 89\%), getting dressed, putting on shoes (81\% vs. 88\%), doing heavy housework (5\% vs. 80\%), doing daily shopping (83\% vs. 89\%), moving around (93\% vs. 97\%). These changes were not statistically significant.

\section{Self-evaluation of the quality of life}

The seniors would most often (78-98\%) declare no problems with regard to questions 1 - 3 or sometimes would feel pain or depression (questions 4 and 5). The figures of the respondents' answers to the questions (in percentage) are shown in figure 1.

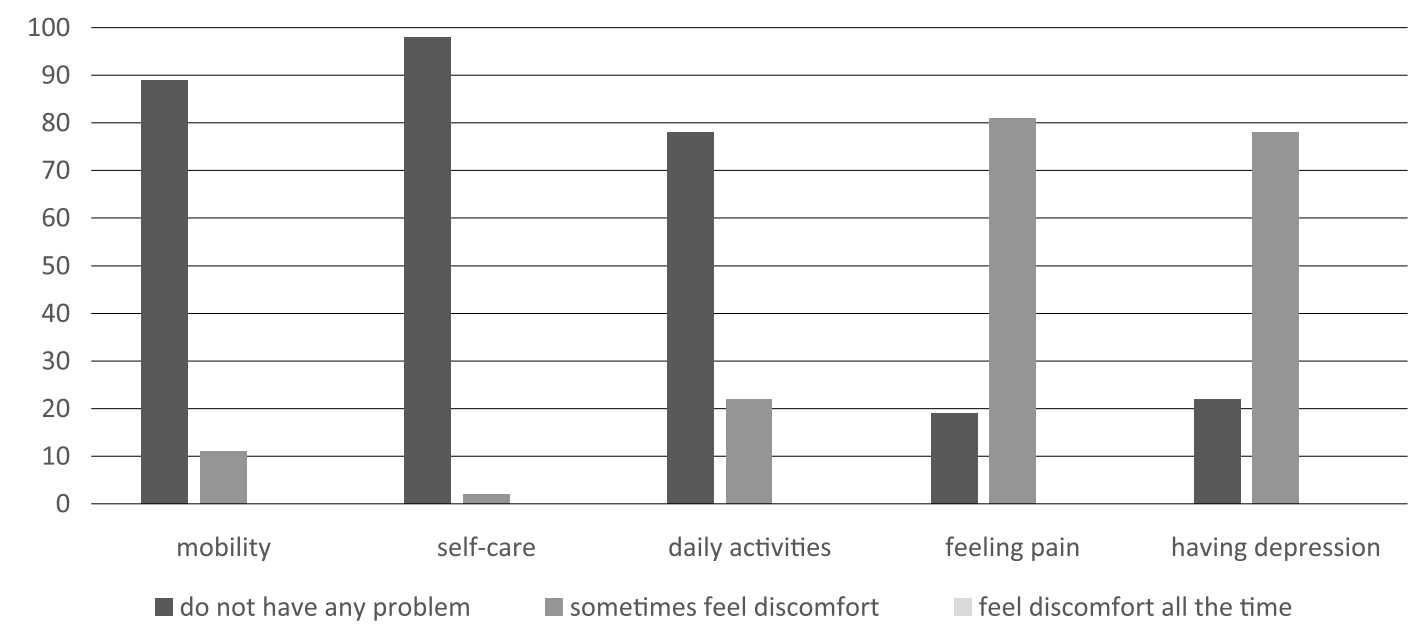

Figure 1. Self-assessment of life quality (questionnaire EQ-5D; $n=73$ ) 
The relationships between questions regarding daily fitness, well-being and self-assessment of own health indicate that, at the same level of declared health, there was a low but significant correlation between one's daily fitness and well-being (correlation coefficient: $0.333^{* *}$ ). A moderate but highly significant correlation (correlation coefficient: $0.490^{* * *}$ ) was found between self-assessment of own health and well-being, at the same level of daily fitness. However, when the declared well-being was the same, there was no significant relationship between daily fitness and self-assessment of own health (correlation coefficient: 0.184).

\section{Objective evaluation of the functional efficiency level}

An accurate objective assessment of the functional efficiency level of the studied group was made by applying the exercises recommended by The Fullerton Functional Fitness Test. The verification of the level of functional efficiency was necessary, as the respondents rated their daily performance very high.

The average results of the exercises are given in the table below (Table 1), broken down by the type of exercise and the date of measurement.

Table 1. Results of the fitness tests

\begin{tabular}{|c|c|c|c|}
\hline Fitness test & Before the programme & After the camp & Norm (60 -74 years) \\
\hline The 2-minute step (n) & $92.0(35-134)$ & $121.3^{* * *}(62-173)$ & $68-107$ \\
\hline 30-second chair stand (n) & $19.9(10-32)$ & $28.8^{* * *}(20-38)$ & $10-17$ \\
\hline Back scratch (cm) & $-1.96(-24-10)$ & $1.00^{* *}(-19-12)$ & $-10-3,75$ \\
\hline Chair sit nad reach (cm) & $5.62(-24-20)$ & $8.25^{*}(-21-24)$ & $-2,5-12,5$ \\
\hline
\end{tabular}

Explanation: The 2-minute step - the number of movement of left and right leg (one step) in 2-minute time; 30-second chair stand - the number of getting-ups and sitting-downs (counted as movements) in 30 seconds; Back scratch - the distance between fingers (negative value when fingers touched one another, positive value when fingers did not touch one another); Chair sit and reach - the distance between toes and fingers.

The study showed that there was an improvement in all the aspects of the tested efficiency. The improvement concerned increased mobility of the upper and lower body, improved muscle strength of the lower limbs and endurance. As for the strength of the lower body, it increased by $32 \%$, in endurance - by $44 \%$, in the mobility of the upper body - by $51 \%$, and in the mobility of the lower body - by $47 \%$.

The changes in mobility as compared to the relevant norms are presented in the graph below (Fig.2).

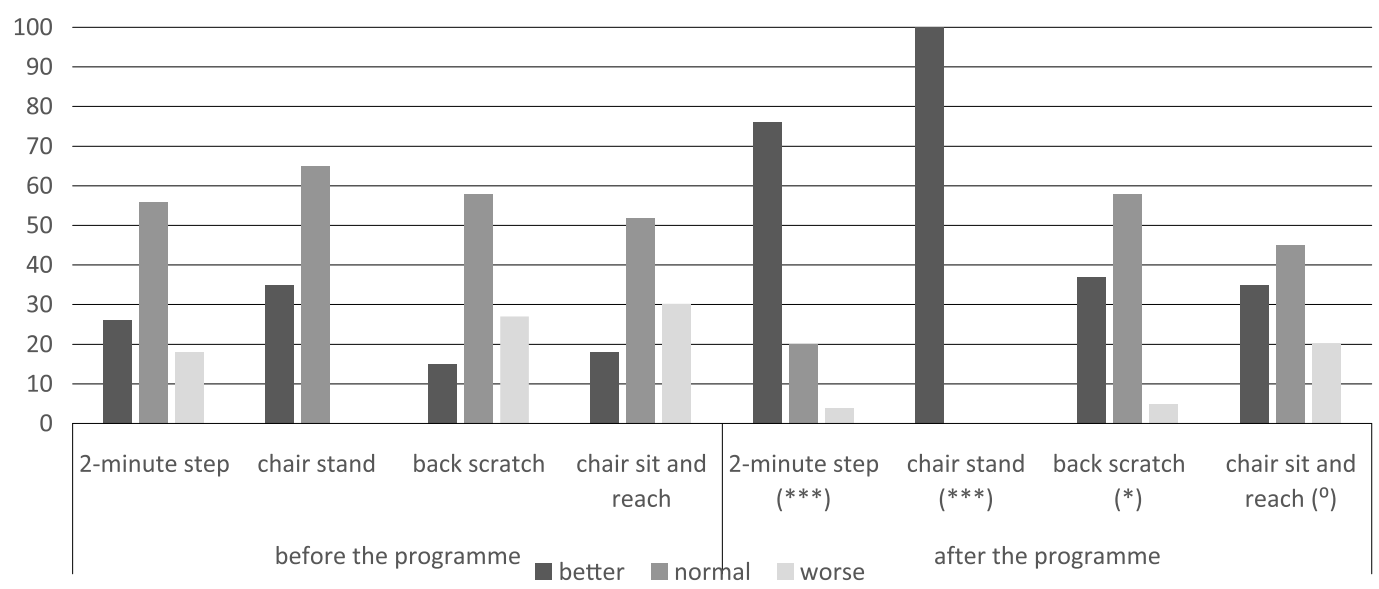

Figure 2. Percentage of the respondents showing changes in selected fitness tests The Fullerton Functional Fitness Test $(\mathrm{n}=$ 73) Significant difference after the programme: $\stackrel{0}{p}<0.05$; $^{*} \mathrm{p}<0.001$

As for the standard norms, there was a noticeable improvement in efficiency in all tests' outcomes. Before the PRROS programme, $78 \%$ of the respondents were classified as not exceeding the norms (or just above standards) in all fitness tests, whereas after the camp ended as many as $99 \%$. In addition, the levels of declared daily performance were compared with the objective fitness assessment. In the case of other fitness tests and functional efficiency self-assessment, there was no correlation between the declared level of functional efficiency and the outcomes of the fitness tests - the values of the correlation coefficients ranged from $-0,078$ to 0,150 and turned out to be insignificant. 


\section{Self-assessment of the quality of life and objective assessment of the level of functional ability}

The results of fitness tests (objective evaluation) were correlated with the total self-assessment of the quality of life found in the EQ-5D questionnaire (subjective assessment). A positive correlation occurred only in relation to the perceived quality of life to the step test: $r=0.246$. In the remaining efficiency tests, there were no significant dependencies - the correlation coefficients ranged from - 0,108 to 0.071

\section{Discussion}

The basic life needs desired by the elderly comprise preserving one's independence, self-sufficiency and fitness. Thus, an essential element is an appropriate diagnosis of the health condition of an elderly person, his/ her level of physical fitness, as well as determining which motor skills require compensatory measures.

It seems significant that the elderly population shows a considerable differentiation of health and level of physical fitness. Their efficiency, concerning instrumental activities in daily life (self-reported functions), personal care and mobility may positively impact enhancing daily performance [24].

As indicated by the analysed data, people who regularly get involved in physical activity assess the level of their functional efficiency better. It can therefore be concluded that physical activity has a significant impact on one's self-assessment of fitness in daily activities, as well as on a better perception of one's independence and self-care. It is also striking that those who have completed PRROS assessed their basic physical functions better (daily activities and self-service) even before taking up regular physical activity. This might be due to the fact that the volunteers participating in the programme had led a more active lifestyle than the others.

Independence in moving around and using transportation is also significant for the elderly. The research confirmed that the examined women were independent in this respect.

In addition to regular physical activity and health, age is the next crucial determinant of an appropriate level of functional fitness. People aged 60-74 years assessed their functional fitness as good.

According to Kostka [25], regular physical activity has a positive effect on the successful ageing process as well as on the proper functioning of the body. It is because taking regular physical activity impacts the respiratory and circulatory system positively, improves muscle flexibility and strength. Further, Kostka [26] underlines the importance of regular physical activity in the physical and mental well-being of the elderly as well as a self-perception of quality of life.

The quality of life of old people is very strongly related to health [24]. It should be remembered that its condition is determined by at least some factors, among which one may mention the pace of natural and individual ageing, past illnesses and injuries, as well as environmental factors. In Maddox's view [27], a proper assessment of health condition in elderly people is also their subjective description, where such self-assessment reveals both the subjective and objective aspects of health. Besides, self-evaluation of health impacts one's duration of life those who assess their health negatively, live shorter, which is not the result of objective indicators [28].

Finally, the analysis carried out in the centres of physical therapy has shown that the persons who completed the 6-month cycle of motor activities and participated in the recreational camp declared a higher number of ailments than before taking up regular physical activity. This may be due to the fact that the persons' body awareness increased in the course of the study and moreover, their perception of own symptoms increased due to the accumulation of joint pains, troubled sleeping or tiredness.

The presented study confirmed that the women whose functional fitness tested objectively was higher assessed their quality of life better $(r=0.751)$. On the other hand, there was no correlation between the subjective assessment of own functional efficiency level and the subjective evaluation of the quality of life ( $\mathrm{r}$ ranged from -0.154 to 0.018 ). This could indicate the level of subjectively assessed functional ability does not have a significant impact on the respondents' experienced quality of life. The studies carried out among inactive and active persons [19] showed that those who were fitter and more active in daily activities, as well as those feeling better or feeling less worried/depressed, assessed their health their quality of life more favourably.

The obtained results indicate that regular, instructor-directed physical activity improves the level of one's functional efficiency (self-service, mobility and performance), health and ultimately the quality of life of females over 60 years. It can, therefore, be said that the Elderly Recreation Programme has successfully influenced the change in the women's PA. Further, the participation in the course significantly improved the respondents' functional efficiency and quality of life. 


\section{Conclusions}

1. There was a noticeable positive relationship between the respondents' regular physical activity and selfassessment of own health condition.

2. A positive relationship was found between participation in daily physical activity, the declared level of functional fitness and the experienced quality of life.

3. The study demonstrated a positive influence of regular physical activity on the self-assessment of quality of life and life satisfaction (statistically significant).

4. There was a positive correlation between the level of objective functional ability and the perceived quality of life in the elderly.

5. There was no significant relationship between the subjective assessment of functional ability and selfassessment of own quality of life.

6. It was demonstrated that the programme of regular physical activity adjusted to the needs of older people positively impacts their functional activity with regard to their mobility, self-service and daily performance.

\section{References:}

1. Wolańska T. Motoryczność ludzi starszych. In: Szwarc H, Wasilewska R, Wolańska T., editors. Rekreacja ruchowa osób starszych. Warszawa: Akademia Wychowania Fizycznego w Warszawie; 1986. p.13-33 (in Polish).

2. Taaffe DR, Marcus R. Musculoskeletal health and the older adult. JRRD 2000; 37: 245-254.

3. Osiński W. Antropomotoryka. Poznań: Wydawnictwo Akademii Wychowania Fizycznego; 2000 (in Polish).

4. Spirduso WW, Francis KL, MacRae PG. Physical Dimensions of Aging. Second Edition. Human Kinetics; 2005.

5. Leś A. Sprawność funkcjonalna jako czynnik warunkujący jakość życia kobiet w starszym wieku. Rozprawa doktorska. Warszawa: Akademia Wychowania Fizycznego w Warszawie; 2009 (in Polish).

6. Szwarc H. Wpływ ruchu i rekreacji fizycznej na somatyczne i psychiczne zdrowie człowieka. In: Dąbrowski K., editors. Zdrowie psychiczne. Warszawa: PWN; 1979. p. 227-232 (in Polish).

7. Baumann K. Jakość życia w okresie późnej dorosłości - dyskurs teoretyczny. Quality of life in old age theoretical discourse. Gerontol Pol. 2006,14(pt 4): 165-171.

8. Kozdroń E, Targosiński P, Szczypiorski P. Zmiany w układzie ruchu osób starszych pod wpływem aktywności ruchowej. Wych. Fiz. Sport 2002, 46 (supl.1, pt 1): 286-287.

9. Kozdroń E. Możliwości uczestnictwa ludzi starszych w zorganizowanych formach rekreacji ruchowej na terenie Warszawy. In: Dąbrowski A., editor. Uczestnictwo Polaków w rekreacji ruchowej i jego uwarunkowania. Warszawa: Akademia Wychowania Fizycznego w Warszawie, Szkoła Wyższa im. Pawła Włodkowica w Płocku, Warszawa-Płock; 2003. p. 145-156 (in Polish).

10. Jopkiewicz A., editor. Aktywność ruchowa osób starszych. Kielce: Wydział Pedagogiczny WSP; 1996 (in Polish).

11. Domański R, Ostrowska A, Rychard A., editors. Jak żyją Polacy. Praca zbiorowa. Warszawa: Wydawnictwo IfiS; 2000 (in Polish).

12. Zysnarska E. Pomiar jakości życia. Wykłady Uniwersytet Mikołaja Kopernika w Toruniu; 2002 (in Polish).

13. Bowling A. What things are important in people lives? A survey of the publics judgments to inform scales of health-related quail of life. Social Science Med. 1995; 41: 1447-1462.

14. Peace SM. Researching social gerontology. Concepts, methods, and issues. London: SAGE Publications; 1990. 15. Bańka A. Psychologia jakości życia. Poznań: Stowarzyszenie Psychologia i Architektura; 2005 (in Polish).

16. Seed P, Lloyd G. Quality of life. Pennsylvania: Jessica Kingsley Publishers; 1997.

17. Leś A, Kozdroń E. Jakość życia i poczucie satysfakcji osób starszych. In: Kubińska Z, Nałęcka D., editors. Rekreacja ruchowa w edukacji i promocji zdrowia, T. 2. Biała Podlaska: Państwowa Wyższa Szkoła Zawodowa im. Papieża Jana Pawła II; 2010 p.91-103 (in Polish).

18. Zielińska-Więczkowska H, Kędziora-Kornatowska K. Determinanty satysfakcji życiowej w późnej dorosłości - w świetle rodzimych doniesień badawczych. Psychogeriatria Polska 2010; 7(1):11-16 (in Polish).

19. Kozdroń E, Leś A. Prozdrowotne efekty aktywnego wypoczynku osób starszych. In: Szczepanowska E, Sokołowski M., editors. Aktywność fizyczna i odżywianie się jako uwarunkowania promocji zdrowia. Poznań: Wielkopolska Wyższa Szkoła Turystyki i Zarządzania; 2008. p. 183-195 (in Polish).

20. Wojszel B, Bień B. Stan zdrowia i sprawność populacji osób w zaawansowanej starości w środowisku dużego miasta i wsi. In: Charzewski J., editor. Problemy starzenia. Warszawa: Akademia Wychowania Fizycznego w Warszawie; 2001. p. 37-53 (in Polish). 
21. Rikli R, Jones J. Measuring functional fitness of older adults. The Journal of active aging. March-April 2002. p. 24-30.

22. Raczek J. Antropomotoryka. Teoria motoryczności człowieka w zarysie. Warszawa: PZWL; 2010 (in Polish).

23. Stupnicki R. Biometria - krótki zarys. Warszawa: Wydawnictwo MAGROS; 2008 (in Polish).

24. Bień B. Sytuacja zdrowotna osób w podeszłym wieku. In: Grodzicki T, Kocemba J, Skalska A. Geriartia z elementami gerontologii ogólnej. Warszawa: Via Medica; 2006; p. 42-46 (in Polish).

25. Kostka T. Promowanie aktywności ruchowej u osób starszych. Medicina Sportiva 2003: 57 (Suppl. 1):37-44 (in Polish).

26. Kostka T. Czynniki determinujące sprawność funkcjonalną i jakość życia osób starszych. In: Dąbrowski A, Rowiński R., editors. Sprawna starość. Warszawa: Akademia Wychowania Fizycznego w Warszawie; 2007. p. 11-19 (in Polish).

27. Maddox GL. Some correlates in self-assessment of health status among the elderly. J. Gerontol. 1967, 17: 449460.

28. Wolinsky FD, Johnson RL, Stump TE. The risk of mortality among older adults over an eight year period. The Gerontologist. 1995, 35:150-161.

29. Biercewiecz M, Szrajda J, Ślusarz R, Kędziora-Kornatowska K, Beuth W. Nervous system disorders in elderly patients and their influence on activities of daily living. Annales UMCS Lublin-Polonia 2005; 60(suppl. 16) 7 D: 19-23.

30. Webster's New World Medical Dictionary, $3^{\text {rd }}$ Edition, Wiley Publishing Inc. 2008.

31. Karabanowicz A, Panas A, Ślusarz R, Beuth W, Grzelak L, Szrajda J. Ocena sprawności funkcjonalnej w chorobach układu nerwowego. Annales UMCS Lublin-Polonia 2005; 60(suppl. 16)190 Sectio D: 352-354. (in Polish). 